\title{
Seasonal changes in energy allocation to somatic and reproductive body components of the common cold temperature sea urchin Loxechinus albus in a Sub-Antarctic environment
}

\author{
Analía F. Pérez · Elba Morriconi · Claudia Boy • \\ Jorge Calvo
}

Received: 31 May 2007 / Revised: 15 September 2007 / Accepted: 18 September 2007 / Published online: 9 October 2007

(C) Springer-Verlag 2007

\begin{abstract}
Monthly variations in the somatic indexes and energetic content of organs were investigated in Loxechinus albus from the Beagle Channel. Samples were collected monthly from May 2004 to May 2005. Lantern and test indexes did not vary significantly. A major peak of gonad index (GI) was observed in winter (sexual maturation period), with a strong declination in November suggesting a spawning period in spring. In coincidence a shortening of feeding activities was expressed by the lower values of gut index (Gut I), suggesting that the gut is a storage organ. The values of gonad energetic content (GEC) and total gonad energetic content (TGEC) showed minimum values in winter (ripe stage) and the maximum in spring (spawned stage). The TGEC reached higher monthly average values $(50-200 \mathrm{~kJ})$ than total gut energetic content (TGuEC) $(20$ $40 \mathrm{~kJ}$ ). These differences indicate that the gonads constitute the most important store organs in L. albus. Moreover, organic stores are built up in the gonads after spawning, and then utilized during gamete production.
\end{abstract}

Keywords Sea urchins - Energetics · Calorimetry · Loxechinus albus $\cdot$ Beagle Channel

\section{Introduction}

In marine high latitude environments the strong seasonality of environmental factors such as temperature and photoperiod

\footnotetext{
A. F. Pérez $(\varangle) \cdot$ E. Morriconi · C. Boy · J. Calvo

Consejo Nacional de Investigaciones Científicas y Técnicas, CONICET. Centro Austral de Investigaciones Científicas,

Bernardo Houssay 200, cp = 9410, Ushuaia,

Tierra del Fuego, Argentina

e-mail: analiafperez@yahoo.com.ar
}

influences markedly food availability (Clarke 1987). Consequently, accumulations of energetic reserves in organisms can show temporal variations. The allocation and distribution of energetic reserves between different body components can provide important information on their functional roles and their relative importance for the survival of the organism (Lawrence 1987; Lawrence and McClintock 1994; Lucas 1996). In order to determine the energetic content of different animal species, two methods are mainly used. The indirect method is based on the determination of biochemical proximal composition. This method estimates the energetic content by using the energetic equivalents of carbohydrates, proteins and lipids (Brody 1945). On the other hand, in the direct method, the energetic content is determined by complete combustion of the sample in a calorimetric bomb (Lucas 1996).

In echinoderms of different latitudes energetic content of body components have been determined by the first method (McClintock and Pearse 1987; McClintock 1989a, b; McClintock et al. 1990a, b; Lawrence and Guille 1982; Lawrence et al. 1984, Lawrence and Moran 1992; Fernandez 1998). However, there is little information available on the relationship between the reproductive cycle and the energy allocation in echinoid organs (Guillou et al. 2000; Brockington et al. 2001).

Many of the sea urchin fisheries show yield oscillations following the declination and recuperation of natural stocks (Keesing and Hall 1998; Andrew et al. 2002; Vadas et al. 2000). For the management of wild populations under extractive pressure knowledge is needed on the reproductive cycles, growth rates, food availability, biochemical composition and energetic budget. Such information is unavailable for many species, including Loxechinus albus (Molina, 1782). In particular the energetic annual budget related to the reproductive cycle of $L$. albus has not been studied yet. 
Loxechinus albus is a species with a wide latitudinal distribution in the Pacific Ocean, from Ecuador $\left(6^{\circ} \mathrm{S}\right)$ to the Beagle Channel, in the south of Tierra del Fuego $\left(54^{\circ} \mathrm{S}\right)$ (Dayton 1985; Bernasconi 1947, 1953; Vásquez and Buschmann 1997). Natural stocks on Chilean coasts have been reduced or depleted due to excessive harvest for commercial purposes (Olave 2001). The Beagle Channel population represents the southernmost limit of the species distribution, exposed to strong variations of the photoperiod, temperature, and marked seasonal fluctuations in primary productivity (Hernando 2006). These variations are reflected in the reproductive cycle (Orler 1992) of L. albus, and probably in its energy allocation.

The objectives of this study were to determinate the energetic content of different organs and their temporal variations over 1 year in relation with the reproductive cycle, and to establish the anatomical location of energetic reserves in a population of $L$. albus located at the southernmost limit of their geographical distribution.

\section{Materials and methods}

Study site and sampling

Adults of L. albus were collected in the Bridges Islands, Beagle Channel $\left(54^{\circ} 50^{\prime} \mathrm{S}\right)$. Monthly samples of 30 individuals were collected by SCUBA diving at a depth of 2-4 m from May 2004 to May 2005. The sea bottom in the sampling area is dominated by boulders and rocky blocks between sandy patches. The rocky substrates give support to encrusted coralline algae (Pseudolitophyllum sp., Synarthrophyton sp.) and holdfasts of brown macroalgae (Macrocystis pyrifera, Lessonia $\mathrm{sp}$.).

The monthly day-length average was provided by the Servicio de Hidrografaía Naval (http://www.hidro.gov.ar/ observatorio/sol/asp). Seawater temperature $\left(0.1^{\circ} \mathrm{C}\right)$ and salinity $(\% \circ)$ were determined in each date of sampling using a Horiba Multianalyzer (Model U-10).

Specimens from 65 to $85 \mathrm{~mm}$ test diameter were selected to minimise the variation in somatic and gonad indexes between individuals (Gonor 1972). Sea urchins were transported to the Ecophysiology Laboratory of CADIC and kept in well aerated, recently filtrated sea water at $7^{\circ} \mathrm{C}$ for $24 \mathrm{~h}$. Each sea urchin was weighed $(0.01 \mathrm{~g})$, and maximum diameter (through the madreporic plate) and height were measured using a electronic calliper $(0.1 \mathrm{~mm})$. Sea urchins were allowed to drip on a paper towel for approximately $1 \mathrm{~min}$ before the whole animal wet weight was recorded.

The celomic liquid was drained from the urchin body cavity (for about $2 \mathrm{~min}$ ) into a pre-weighted glass jar by sectioning the peristomal membrane. The removed liquid was then weighted. Animals were dissected and body wall (test, spines and peristomal membrane), Aristotle's lantern, gut (voided of food content), and gonads were weighted separately (0.01 g).

The indexes of different body components (gonad, gut, celomic liquid, test and Aristotle's lantern) were calculated as organ wet weight $(\mathrm{g}) \times 100 /$ total wet weight $(\mathrm{g})$. The organic content of test and lantern expressed as percentage of total dry mass were measured by ashing body component for $6 \mathrm{~h}$ in a muffle furnace at $450^{\circ} \mathrm{C}$ (Paine 1971).

Calorimetric determination

Gonads and gut were dried in an air-circulating stove at $70^{\circ} \mathrm{C}$ to constant weight. After obtaining the dry mass, samples were ground and pellets were made with a press (Parr model 2812). The caloric contents of gonads and guts of approximately 20 individuals (10 females and 10 males) were obtained per month by burning pellets $(50-200 \mathrm{mg}$ ) in a micro-bomb calorimeter (Parr model 1425) as described by Lucas (1996). The values obtained were corrected for ash and acid content and were expressed as $\mathrm{kJ} / \mathrm{g}$ ash free dry mass (AFDM). Benzoic acid calibrations were periodically done. The total energetic content of gonad (TGEC) and gut was calculated as $\mathrm{kJ} / \mathrm{g}$ ash free dry mass $($ AFDM $) \times$ total dry weight of organ $(\mathrm{g})$.

Statistical analysis

Monthly differences in the indexes and energetic content in each group of organs were analyzed using an analysis of variance (ANOVA). The assumptions of normality (Kolmogorov-Smirnov test) and homogeneity of variances (Levene's test) were tested and transformations were applied when necessary. Significant differences were analyzed by unplanned Tukey-Kramer multiple comparisons test. When a nonparametric test was used (Kruskal-Wallis), differences were analysed using unplanned Dunn's multiple comparisons test (Zar 1984; Sokal and Rohlf 1995). Statistical analyses were performed with Statistica 6.0 and GraphPad Instat packages.

\section{Results}

\section{Environmental factors}

Minimum day length occurred in June $(7.3 \mathrm{~h})$ and maximum in December $(17.4 \mathrm{~h})$. The increase in photoperiod is followed by an increase in the water temperature. Monthly minimum $\left(4^{\circ} \mathrm{C}\right)$ and maximum $\left(10.5^{\circ} \mathrm{C}\right)$ mean seawater temperature was recorded in June and February, respectively (Fig. 1). Sea surface salinity values ranged from $29.6 \%$ (December) to $31.7 \%$ (July). The seasonal phytoplankton biomass (as chlorophyll- $a$ ) values were minimum during the austral autumn and winter $(\approx 0.3 \mu \mathrm{g} / \mathrm{l})$, whereas were maximum during late spring and early summer $(\approx 10 \mu \mathrm{g} / \mathrm{l}$; Hernando 2006). 


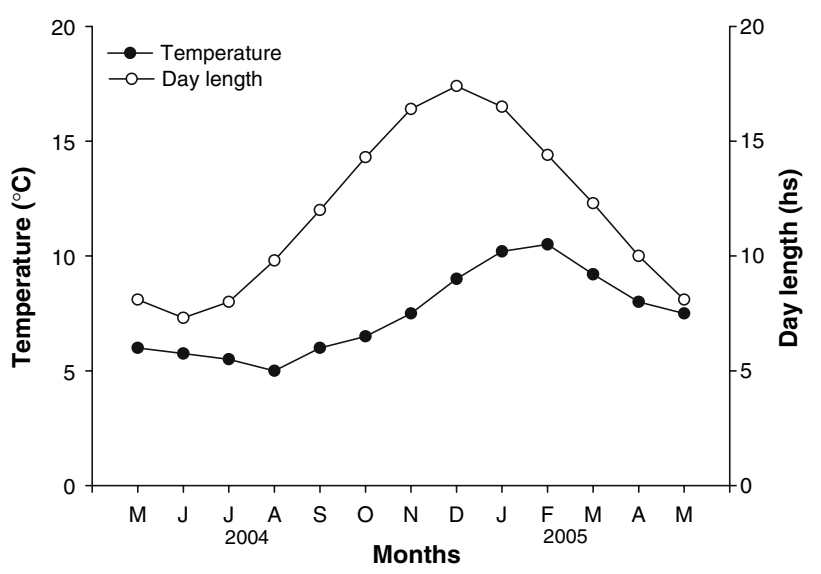

Fig. 1 Monthly means of seawater temperature and day length in Bridges Islands $\left(54^{\circ} 50^{\prime} \mathrm{S}, \mathrm{L}\right)$, Beagle Channel

Somatic and gonad indexes

Monthly values of gonad index (GI) were not different between females $(n=190)$ and males $(n=190)$ (Student's $t=0.99, P=0.32$ ). Therefore, both sexes were considered together. The differences between monthly values were highly significant (Kruskal-Wallis; $H=177.26, P<0.001$; Fig. 2a), with higher values showing a semiannual pattern peaking in March, April, July and August, and lower values in November and May $(P<0.05)$.

The gut index (Gut I) varied significantly throughout the year (one-way ANOVA $F=10.73, P<0.001$; Fig. 2b), also with a semiannual pattern. It was lower in May, October and November, whereas the highest values were recorded in August $(P<0.05)$ and between December and April $(P<0.05)$.

Significant differences were found in the celomic liquid index (Liq. I) (Kruskal-Wallis; $H=67.47, P<0.001$; Fig. 2c) throughout the year, being higher in May and June and lower in August and April $(P<0.05)$.

Finally, lantern index (mean $=2.82, \mathrm{SD}=0.37, n=260)$ and test index (mean $=39.46, \mathrm{SD}=2.18, n=260)$ did not vary significantly throughout the year $(P>0.05)$.

Organic matter of test and lantern

The organic matter percentage in lantern and test (mean $=12.32, \mathrm{SD}=0.99, n=130$ and mean $=11.30$, $\mathrm{SD}=0.71, n=106$, respectively) did not vary significantly throughout the year $(P>0.05)$.

\section{Gonad energetic content}

The mean gonad energetic content (GEC) was higher in females $(27.59 \pm 1.55 \mathrm{~kJ} / \mathrm{g}, n=128)$ than males $(26.12 \pm$ $1.60 \mathrm{~kJ} / \mathrm{g}, n=117$; Fig. 3). The GEC varied significantly
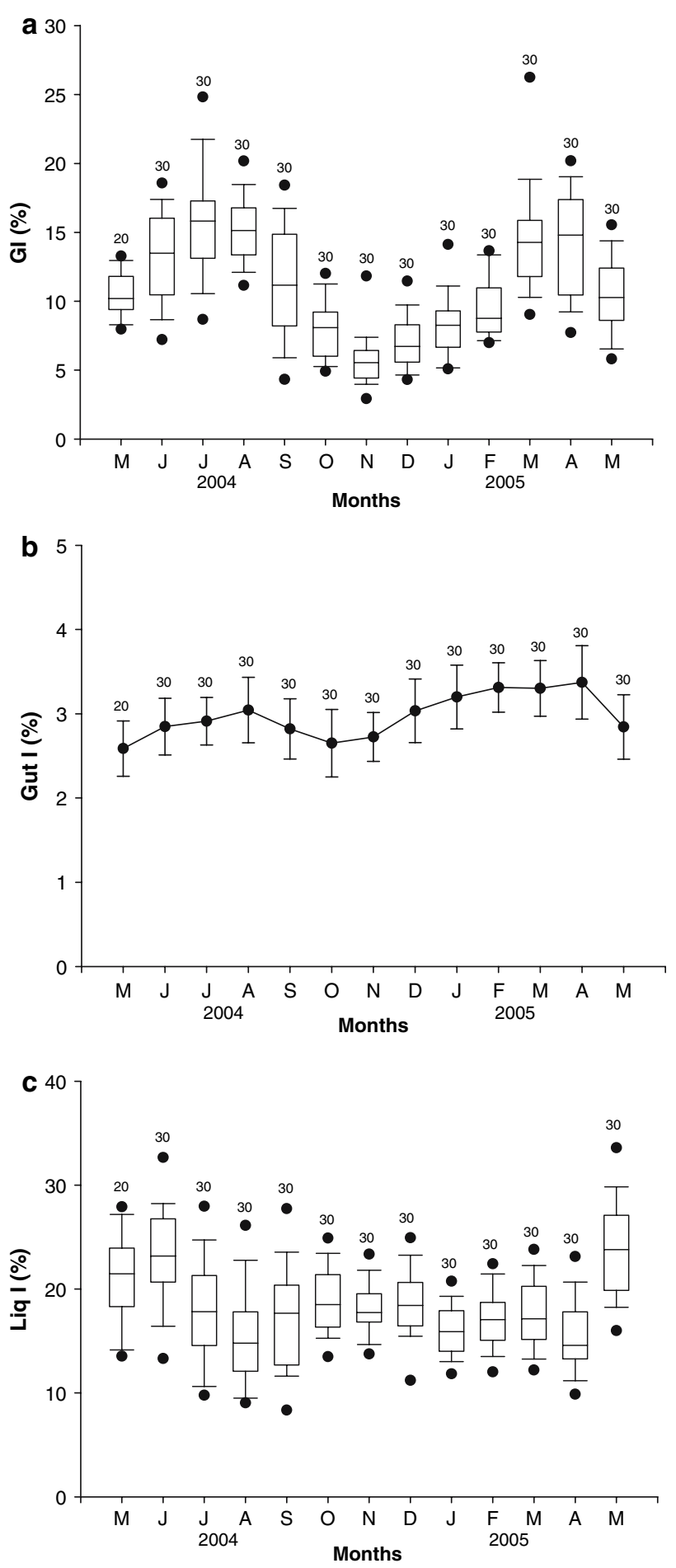

Fig. 2 Loxechinus albus from Bridges Islands. Monthly variation. a Gonad index (GI), median, quartiles and data outside 5th and 95th percentiles are indicated ( $n$ given above data outside), b gut index (Gut I), mean and standard error ( $n$ given above error bars), $\mathbf{c}$ liquid index (Liq I), median, quartiles and data outside 5 th and 95 th percentiles are indicated ( $n$ given above data outside)

throughout the year for both males and females. The interaction between month and sex was not significant (two-way ANOVA, $F=1.76, P>0.05)$. Differences attributable to 


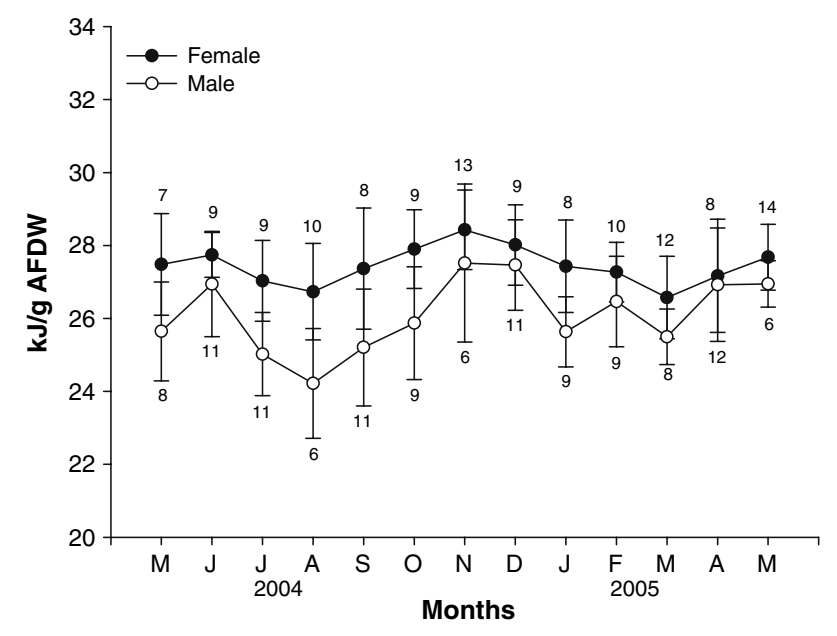

Fig. 3 Loxechinus albus from Bridges Islands. Energetic content of gonads (GEC; kJ/g AFDW, mean and SD; $n$ of female given above error bars and $n$ of males given below error bars)

months $\quad(F=3.72, \quad P<0.001)$ and sex $(F=58.44$, $P<0.0001)$ were found. The GEC for females reached the maximum in November $(P<0.05)$ and the minimum in August and March, while in males these values were higher in November, December, April and May and lower in August $(P<0.05$; Fig. 3$)$.

Gut energetic content

The mean gut energetic content (GuEC) was $24.82 \pm 1.14 \mathrm{~kJ} /$ $\mathrm{g}(n=129)$ for females and $25.11 \pm 1.35 \mathrm{~kJ} / \mathrm{g}(n=119)$ for males (Fig. 4). The monthly mean GuEC value varied significantly throughout the year. Interaction between month and sex was not significant (two-way ANOVA, $F=1.01$, $P>0.05)$. These differences were attributable to months

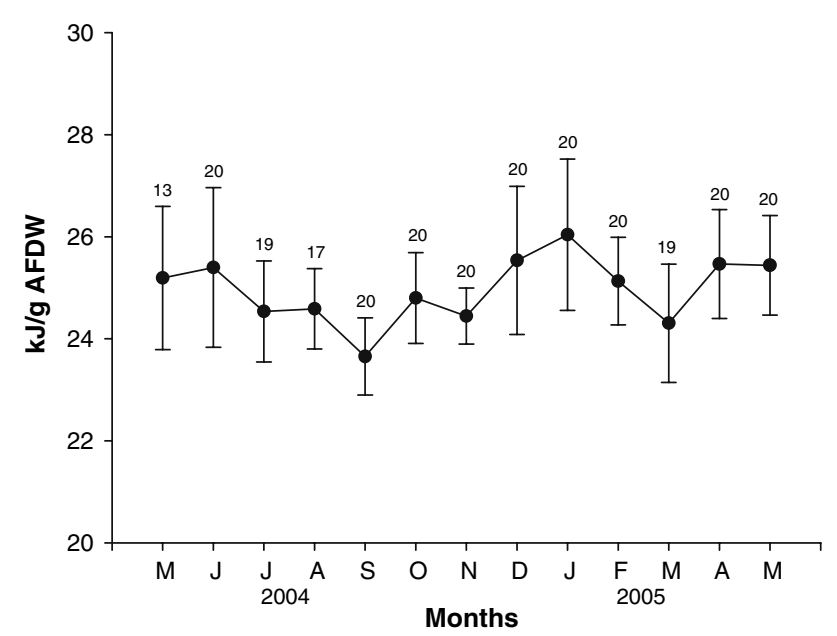

Fig. 4 Loxechinus albus from Bridges Islands. Energetic content of gut (GuEC; kJ/g AFDW; mean and SD; $n$ given above error bars)
$(F=7.27, P<0.001)$ but not to sex $(F=3.38, P>0.05)$. The lower GuEC value found in September was different $(P<0.05)$ from the maximum values found between December and February and between April and June.

Total energetic content of gonad

The mean total energetic content of gonad was $118.54 \pm 59.79 \mathrm{~kJ} \quad(n=125) \quad$ for females and $94.45 \pm 38.88 \mathrm{~kJ}(n=117)$ for males.

The TGEC varied significantly throughout the year (Fig. 5). The interaction between month and sex was not significant (two-way ANOVA, $F=0.83, P>0.05$ ). The differences were attributable to months $(F=14.44$, $P<0.001)$ and sex $(F=20.08, P<0.001)$. The TGEC was lower in November $(P<0.05)$ and maximum values were found in July and March $(P<0.05)$.

Total energetic content of gut

Both sexes were analyzed together because monthly values of total energetic content of gut (TGuEC) between females $75.68 \pm 11.80 \mathrm{~kJ}(n=128)$ and males $73.59 \pm 12.40 \mathrm{~kJ}$ ( $n=119$ ) were not different (Mann-Whitney test $U=6754$, $\left.U^{\prime}=8478, P>0.05\right)$. Monthly differences were highly significant (Kruskal-Wallis; $H=110.63, P<0.001$; Fig. 6). From May to November the values were lower, being higher from December to April $(P<0.05)$.

\section{Discussion}

Great seasonal fluctuations in environmental parameters, such as productivity, temperature and photoperiod (Fig. 1)

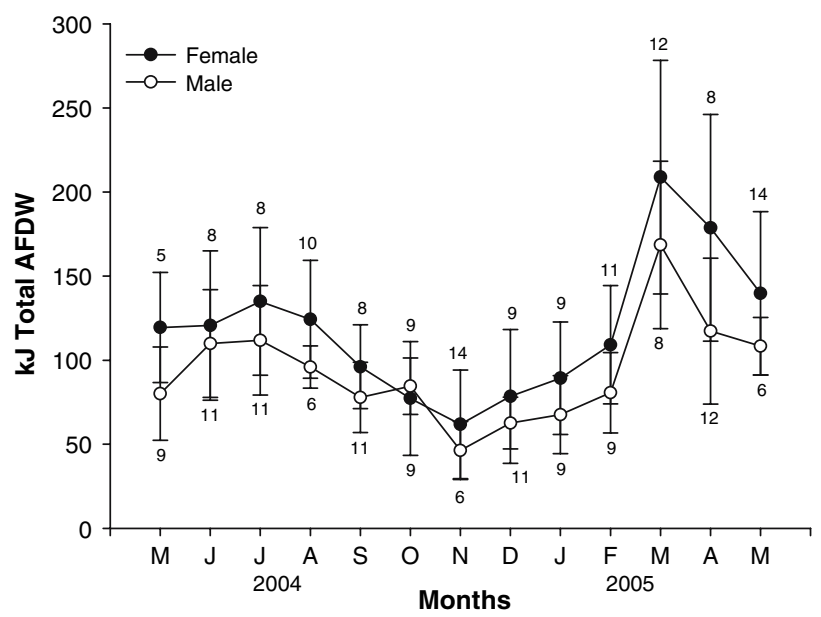

Fig. 5 Loxechinus albus from Bridges Islands. Total energetic content of gonad (TGEC; kJ total AFDW; mean, and SD; $n$ of female given above error bars, $n$ of males given below error bars) 


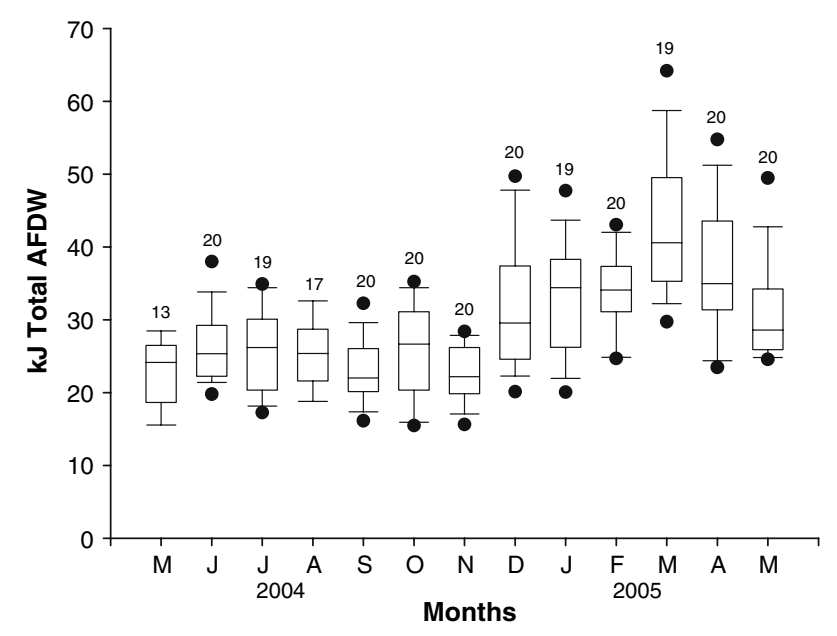

Fig. 6 Loxechinus albus from Bridges Islands. Total energetic content of gut (TguEC; kJ total AFDW; median, quartiles and data outside 5th and 95 th percentiles are indicated; $n$ given above data outside).

have been described in Antarctic (Clarke 1988; Clarke et al. 1988; Peck 2005) and Sub-Antarctic (Beagle Channel; Hernando 2006) regions. Studies on the relationships between environmental fluctuations and biological cycles could be a source of relevant knowledge to analyze the effects of global climatic changes on high latitude organisms.

The temporal variation in the GI (Fig. 2a) suggests an annual gonadal cycle of the studied Loxechinus albus population. This result is also supported, by a preliminary histological study on ovaries of $L$. albus (Pérez et al. unpublished data) which showed a period of absence of maturing oocytes from October to February. These observations show a strong difference with the gametogenic cycle of some Antarctic sea urchins (e.g., S. neumayeri), whose oocytes develop fully over a 2-year period (Pearse and Giese 1966)

The changes in GI values were caused by the presence of variable quantities of both nutritive phagocytes and gametes in different stages of development (Walker et al. 2007; Pérez et al. unpublished data). A major peak of GI was observed in July and August, followed by a spawning period in spring (September to December).

Populations of $L$. albus inhabiting the Southern Pacific coast (Punta Arenas, $53^{\circ} \mathrm{S}$ ) spawn in July-September (Oyarzun et al. 1999), and in September-October (BaySchmidt et al. 1981). Some populations situated in northern localities spawn earlier in the year $\left(23^{\circ} \mathrm{S}\right.$ : June; $30^{\circ} \mathrm{S}$ : JuneAugust; Guisado et al. 1995). Conversely, populations of intermediate latitudes spawn in a period similar to those from southern populations $\left(32^{\circ}-33^{\circ} \mathrm{S}\right.$ : August-November; $42^{\circ}-45^{\circ} \mathrm{S}$ : November-December; Guisado et al. 1995). Vazquez (2007) reviewed this data and attributed the differences in timing of Southern populations to the influence of Cape Horn Current.
However, the presence of a second peak of GI in autumn (March-April) did not indicate a second sexual maturation because the gonads were in non-mature stages (Pérez et al. unpublished data). The increase of GI in autumn could be due to the raise of non-gametic component of gonads as nutritive phagocytes as was described in Walker et al. (2007). Probably the subsequent decrease during May (both years of sampling; Fig. 2) might be due to utilization of nutrients stored in gonads before the start of sexual maturation.

When the gonads reach the ripeness and maximum volume, the internal body cavity is reduced. In consequence the celomic liquid quantity decreases and therefore the Liq I also diminishes (Fig. 2c) showing an inverse variation to GI (Fig. 2c). The lower values of Gut I found in spring (Fig. 2b) suggest some shortening in feeding activities in coincidence with spawning (lower GI values; Fig. 2a). After the spawning period (November to April), L. albus exhibits an increase in Gut I (Fig. 2b). The energy expended in spawning could be restored by a high rate of ingestion. This was found in the same species in Chilean coasts (Bückle et al. 1980) and also in Strongylocentrotus intermedius studied in captivity in Japan (Fuji 1962). Some species of sea urchins can suffer a depression in feeding rate during the spawning period (Lawrence 1975), and a similar pattern is shown by $S$. intermedius under experimental conditions (Fuji 1962). In captivity, L. albus shows a low rate of natural food ingestion during the reproductive season (Cárcamo 2004). Studies of S. purpuratus and S. franciscanus have shown that the relative size of the gut varies seasonally; this fluctuation may be reflecting the "nutritional condition" of the sea urchins (Lawrence et al. 1965; Pearse et al. 1970).

In this study the Gut I of L. albus shows a variation along the sampling period (Fig. 2b). Therefore, these results allow considering the gut as a storage organ in coincidence with previous results (Lawrence et al. 1966; Klinger et al. 1988). When food availability is low or during starvation, the gut epithelium decreases in size (Lawrence et al. 1965), the thickness of the gut wall diminishes, and intestinal lumen decreases (Bishop and Watts 1992).

The test and Aristotle's lantern of $L$. albus do not seem to play a role in nutrient storage because the lantern and test indexes, as the percentage of organic matter did not show significant variation throughout the year. Although the sea urchin test contains a greater absolute mass of organic material than other body components, it shows low levels of carbohydrate and lipids and an absence of specialized nutrient storage cells, which suggest its nonsignificant role in energy storage (Lawrence and Guille 1982). However, the lantern could increase their relative size in relation with a shortening of food availability (Ebert 1980; Black et al. 1982; Levitan 1991). 
The analysis of the relationship between the reproductive cycle, the energy storage and its utilization, allows understanding the internal energy transfer process for a given species (Lucas 1996). Previously, biochemical composition (Galley et al. 2005; Brockington et al. 2001), and organic matter content (Lares and Pomory 1998) were used to determine the energetic storage organs. The present study represents the first attempt to analyse the energetic content of different organs using calorimetric determinations in sea urchins.

The energetic reserves can be accumulated in gut, gonads, body wall, Aristotle's lantern and celomic liquid. Gut and gonads are considered to play a major role in nutrient store in sea urchins (Brockington et al. 2001; Lawrence et al. 1965). Therefore, a variation in their indexes and energetic content through the year is expected.

This study shows few variations in monthly values of GEC (between 24 and 28 kJ/g AFDW; Fig. 3) suggesting a stable biochemical composition. These values are similar at the findings in the Antarctic sea urchin Sterechinus neumayeri (Brockington et al. 2001) resulting close to energetic value of protein (Brody 1945; Lucas 1996). The GEC in L. albus showed the minimum in August (ripe stage) and the maximum in November (spawned stage; Fig. 3). This variation could be due to the changes in the proportion of nutritive phagocytes with respect to gametes. The first kind of cells declines in the ripe gonads, increasing their number when the spawning occurs (Orler 1992; Pérez et al. unpublished data). These cells contain vacuoles with proteins, neutral mucopolysaccharides and lipids (Walker et al. 2007), explaining thus the high energetic values (Figs. 3 and 5) found in the spent gonads of L. albus (Fig. 2a). The energetic content $(\mathrm{kJ} / \mathrm{g}$ AFDW) is higher in ovaries than testes (Fig. 3) because the first one contains higher levels of lipid (McClintock and Pearse 1987).

The mean monthly values of GuEC (kJ/g AFDW) were lower than the GEC (Figs. 3 and 4) probably because the gonads contain a higher level of lipids than the gut. A similar pattern was found in Ctenocidaris perrieri, Abatus shackletoni, Abatus nimrodi and Sterechinus neumayeri (McClintock 1989a; McClintock and Pearse 1986, 1987; Brockington et al. 2001).

When Loxechinus albus rises the ingestion rate after the spawning period (from November to March; Fig. 2b), the GuEC (kJ/g AFDW; Fig. 4) increases until January, whereas the total energetic content increases until March (Fig. 6). Likewise, Strongylocentrotus intermedius in captivity (Fuji 1962) and Loxechinus albus studied in the Pacific coast (Cárcamo 2004; Bückle 1980) show high rates of food ingestion after the spawning period.

The TGEC and TGuEc (Figs. 5 and 6) shows that the first one have higher monthly average values $(50-200 \mathrm{~kJ}$ total AFDW) than the second (20-40 kJ total AFDW).
These differences indicate that the gonads are the most important store organ in Loxechinus albus.

Acknowledgments We thank Daniel Aureliano, Marisa Machado, Marcelo Gutiérrez and Sonia Rimbau for their technical assistance, Noelia Carmona for assistance with the English manuscript and Pedro Francisco Cárcamo for his generous advice. This research was supported by P.I.P. 02944 (CONICET), and Subproyecto A-B-21 (PNUDARG/02/018).

\section{References}

Andrew NY, Agatsuma A, Bazhin E, Creaser D, Barnes L, Botsford A Bradbury A, Campbell S, Einnarsson P, Gerring K, Hebert M, Hunter SB, Hur C, Johnson MA, Juinio-Meñez P, Kalvass R, Miller C, Vadas D, Woobdy Z, Xiaoqui (2002) Status and management of world sea urchins fisheries. Oceanogr Mar Biol Ann Rev 40:343-425

Bay-Schmith E, Werlinger C, Silva J (1981) Ciclo anual de reproducción del recurso erizo Loxechinus albus entre la X y XII Region. Informe final. Proyecto de investigacion, Subsecretaria de Pesca, Universidad de Concepción, 1-66

Bernasconi I (1947) Distribución geográfica de los equinoideos argentinos. An Soc Arg Est Geog 6:97-114

Bernasconi I (1953) Monografía de los Equinoideos argentinos. An Mus Hist Nat Montevideo 6(2):23-25

Bishop CD, Watts SA (1992) Biochemical and morphometric study of growth in the stomach and intestine of de echinoid Lytechnius variegates (Echinodermata). Mar Biol 144:459-467

Black R, Johnson MS, Trendall JT (1982) Relative size of Aristotle's lantern in Echinometra mathaei occurring at different densities. Mar Biol 71:101-106

Brody S (1945) Bioenergetics and growth. Reinhold Publishing, New York

Brockington S, Clarke A, Chapman ALG (2001) Seasonality of feeding and nutritional status during the austral winter in the Antarctic sea urchin Sterechinus neumayeri. Mar Biol 139:127-138

Bückle F, Alveal K, Tarifeño E, Guisado Ch, Córdova L, Serrano C, Valenzuela J (1980) Biological studies in the Chilean sea urchin Loxechinus albus (Molina) (Echinodermata: Echinoidea): food analysis and seasonal feeding rate. An Cen Cienc Mar Limnol Univ Nal Auton México 7(1):149-158

Cárcamo PF (2004) Effect of diet on gonadal and somatic production of the sea urchin Loxechinus albus under sea based cultivation conditions. In: Lawrence JM, Guzmán O (eds) Sea urchins: fisheries and ecology. Destech, Lancaster, pp 222-229

Clarke A (1987) Temperature, latitude and reproductive effort. Mar Ecol Prog Ser 38:89-99

Clarke A (1988) Seasonality in the Antarctic marine environment. Comp Biochem Physiol 90:461-473

Clarke A, Holmes LJ, White MG (1988) The annual cycle of temperature, chlorophyll and mayor nutrients at Signy Island, South Orkney Islands, 1969-82. Br Antarct Surv Bull 80:65-86

Dayton PK (1985) The structure and regulation of some South American kelp communities. Ecol Monogr 55(4):447-468

Ebert TA (1980) Relative growth of sea urchin jaws: an example of plastic resource allocation. Bull Mar Sci 30:467-474

Fernandez C (1998) Seasonal changes in the biochemical composition of the edible sea urchin Paracentrotus lividus. Mar Ecol 19:1-11

Fuji A (1962) Studies on the biology of the sea urchin V. Food consumption of Strongylocentrotus intermedius. Jap J Ecol 12:181-186

Galley EA, Tyler PA, Clarke A, Smith CR (2005) Reproductive biology and biochemical composition of the brooding echinoid 
Amphipneustes lorioli on the Antarctic continental shelf. Mar Biol 148:59-71

Guillou M, Lumingas LJL, Michel C (2000) The effect of feeding or starvation on resource allocation to body components during the reproductive cycle of the sea urchin Sphaerechinus granularis (Lamarck). J Exp Mar Biol Ecol 245:183-196

Guisado Ch (1995) Estrategias de desarrollo larval y ciclo de vida en dos especies de echinoideos regulares del sur de Chile. M Sc Thesis, Universidad Austral de Chile, Valdivia, Chile

Gonor JJ (1972) Gonad growth in the sea urchin Strongylocentrotus purpuratus (Stimpson) (Echinodermata: Echinoidea) and the assumptions of gonad index methods. J Exp Mar Biol Ecol 19:89103

Hernando MP (2006) Efectos de la radiación solar sobre el fitoplancton de aguas Antárticas y sub-Antárticas. PhD Thesis, Universidad de Buenos Aires, Facultad de Ciencias Exactas y Naturales, Buenos Aires, Argentina

Keesing JK, Hall KC (1998) Review of harvests of status of world sea urchins fisheries points to opportunities of aquaculture. J Shellfish Res 17:1597-1604

Klinger TS, Watts SA, Forcucci D (1988) Effect of short-term feeding and starvation on storage and synthetic capacities of gut tissue of Lytechinus variegatus (Lamarck) (Echinodermata:asteroidea). J Exp Mar Biol Ecol 117:187-195

Lares MT, Pomory CM (1998) Use of body components during starvation in Lytechinus variegatus (Lamarck) (Echinodermata: Echinoidea). J Exp Mar Biol Ecol 225:99-106

Lawrence JM (1975) On the relationship between marine plants and sea urchins. Oceanogr Mar Biol Ann Rev 13:213-286

Lawrence JM (1987) Bioenergetics of echinoderms. In: Keegan BF, O'Connor DS (eds) Echinodermata. Balkema, Rotterdam, pp 47 67

Lawrence JM, Guille A (1982) Organic composition of tropical, polar and temperate-water echinoderms. Comp Biochem Physiol $72 \mathrm{~B}(2): 283-287$

Lawrence JM, Moran P (1992) Proximate composition and allocation of energy to body components in Acanthaster planci (Linnaeus) (Echinodermata: Asteroidea). Zool Sci 9:321-328

Lawrence JM, McClintock JB (1994) Energetic acquisition and allocation by echinoderms (Echinodermata) in polar seas: adaptations for success? In: David B, Guille A, Feral JP, Roux M (eds) Echinoderms through time (Echinoderms Dijon). Balkema Press, Rotterdam, pp 39-52

Lawrence JM, McClintock JB, Guille A (1984) Organic level and caloric content of eggs of brooding asteroids and an echinoid (Echinodermata) from Kerguelen (South Indian Ocean). Int J Invert Repro Develop 7:249-257

Lawrence JM, Lawrence AL, Holland ND (1965) Annual cycle in the size of the gut of the purple sea urchin Strongylocentrotus purpuratus (Stimpson). Nature 205:1238-1239

Lawrence JM, Lawrence AL, Giese AC (1966) Role of the gut as a nutrient-storage organ in the purple sea urchin (Strongylocentrotus purpuratus). Physiol Zool 39:281-290

Levitan DR (1991) Skeletal changes in the test and jaws of the sea urchin Diadema antillarum when food-limited. Mar Biol 106:431-435

Lucas A (1996) Energetics of aquatic animals. Taylor and Francis, London
McClintock JB, Pearse JS (1986) Organic and energetic content of eggs and juveniles of Antarctic echinoids and asteroids with lecithotrophic development. Comp Biochem Physiol 85A:341-345

McClintock JB, Pearse JS (1987) Biochemical composition of antartic echinoderms. Comp Biochem Physiol 86B(4):683-687

McClintock JB (1989a) Energetic composition, reproductive output, and resource allocation of Antarctic asteroids. Polar Biol 9:147153

McClintock JB (1989b) The biochemical and energetic composition of somatic tissues during growth in the sea star, Pycnopodia helianthoides (Echinodermata, Asteroidea). Comp Biochem Physiol 93A(4):695-698

McClintock JB, Hopkins T, Watts SA, Marion K (1990a) The biochemical and energetic composition of somatic body components of echinoderms from the northern gulf of Mexico. Comp Biochem Physiol 95A(4):529-532

McClintock JB, Cameron JL,Young CM (1990b) Biochemical and energetic composition of bathyal echinoids from the Bahamas. Mar Biol 105:175-183

Olave S, Bustos E, Lawrence JM,Cárcamo P (2001) The effect of size and diet on gonad production by the Chilean sea urchin Loxechinus albus. J World Aquacult Soc 32(2):210-214

Orler PM (1992) Biología reproductiva comparada de Pseudechinus magellanicus y Loxechinus albus, equinoideos del Canal Beagle. PhD Thesis, Univesidad Nacional de La Plata, Facultad de Ciencias Naturales y Museo, La Plata, Buenos Aires, Argentina

Oyarzún ST, Marín SL, Valladares C, Iriarte JL (1999) Reproductive cycle of Loxechinus albus (Echinodermata: Echinoidea) in two areas of the Magullen region $\left(53^{\circ} \mathrm{S}, 70-72^{\circ} \mathrm{W}\right)$, Chile Sci Mar 63:439-449

Paine RT (1971) The measurement and application of the calorie to ecological problems. Ann Rev Ecol Syst 2:145-164

Pearse JS, Giese AC (1966) Food, reproduction, and organic constitution of the common antarctic echinoid Sterechinus neumayeri. Biol Bull 130:387-401

Pearse JS, Clark ME, Leighton DL, Mitchell CT, North WJ (1970) Marine waste disposal and sea urchin ecology. In: Kelp habitat improvement project, Annual Report, Pasadena, California, pp 87

Peck LS (2005) Prospects for surviving climate change in Antarctic aquatic species. Front Zool. doi:10.1186/1742-99942-9

Sokal RR, Rohlf FJ (1995) Biometry: the principles and practice of statistics in biological research. W H Freeman, New York

Vadas RL, Beal B, Dowling T, Fegley JC (2000) Experimental field tests of natural algal diets on gonad index and quality in the green sea urchin, Strongylocentrotus droebachiensis: a case for rapid summer production in post-spawned animals. Aquacult 182:115135

Vásquez JA (2007) Ecology of Loxechinus albus In: Larence JM (ed) Edible sea urchins: biology and ecology, 2nd edn. Elsevier, Amsterdam, pp 227-241

Vásquez JA, Buschmann AH (1997) Herbivore-kelp interactions in Chilean subtidal communities: a review. Rev Chile Hist Nat 70:41-52

Walker CW, Unuma T, Lesser MP (2007) Gametogenesis and reproduction of sea urchins. In: Lawrence JM (ed) Edible sea urchins: biology and ecology, 2nd edn. Elsevier, Ámsterdam, pp 12-33

Zar JH (1984) Biostatistical analysis. Prentice-Hall, New Jersey 